\title{
HUBUNGAN LAMA PENGGUNAAN KB IMPLANT DENGAN JUMLAH KELUHAN PADA AKSEPTOR DI PUSKESMAS JUNREJO KOTA BATU
}

\author{
Long Relationship With The Use of Kb Implant Number of Complaints On Health Junrejo \\ Acceptors In Stone Town
}

Tri Lestari Handayani ${ }^{1}$, Atok Miftachul Huda ${ }^{2}$, Winda Riski ${ }^{3}$

\author{
${ }^{1,2)}$ Program Studi Ilmu Keperawatan Fakultas Ilmu Kesehatan Universitas Muhammadiyah Malang \\ ${ }^{3)}$ Alumni Mahasiswa Program Studi Diploma III Keperawatan Fakultas Ilmu Kesehatan Universitas \\ Muhammadiyah Malang \\ Jl. Bendungan Sutami 188A Malang 65145 \\ *e-mail: tari_1971@yahoo.com
}

\begin{abstract}
ABSTRAK
Implant adalah alat kontrasepsi yang disusupkan di bawah kulit lengan atas sebelah dalam, berbentuk kapsul silastik (lentur), panjangnya sedikit lebih pendek dari korek api. Penggunaan KB implant dapat diganti setiap 3 atau 5 tahun dan ada juga yang setiap tahun, dari penggunaan KB implant banyak akseptor yang mengeluhkan terjadinya perubahan pada berat badan, haid yang tidak teratur, amenore, dan nyeri haid. Untuk mengetahui apakah ada hubungan lama penggunaan KB implant dengan jumlah keluhan pada akseptor di Puskesmas Junrejo Kota Batu. Desain penelitian yang digunakan adalah deskriptif korelasional. Populasi penelitian akseptor KB implant di Puskesmas Junrejo Kota Batu berjumlah 23 responden. Pengumpulan data pada penelitian ini menggunakan kuesioner. Hasil penelitian menunjukkan dari perhitungan analisis data menggunakan regresi linier sederhana diketahui p value $0.656>0.25$, hal ini berarti Ho diterima dan $\mathrm{Hi}$ ditolak, yang artinya tidak ada hubungan antara lama penggunaan KB implant dengan jumlah keluhan. Peneliti menyarankan pada pelayanan kesehatan untuk lebih menjelaskan keuntungan dan kerugian dalam pemakaian KB implant.
\end{abstract}

Kata kunci: lama penggunaan KB implant, jumlah keluhan

\begin{abstract}
Implant is a contraception tool that inserted under arm skin on top of inside, have the shape of silastic capsule (flexible), length a little shorter from match. Use of KB implant replaceable every 3 or 5 years and there also every year, from use of KB implant many acceptors that sigh the happening of change in heavy body, menstruation not regular, amenore, and menstruation pain. To detect is there the relation of long use of KB implant with complaint quantity in acceptor at Local Government Clinic of Junrejo Batu City. Research design that used is descriptive correlation. Research population of KB implant acceptor at Local Government Clinic of Junrejo Batu City is 23 respondents. Data collecting in this research is using questionnaire. Research result shows from data analysis calculation by using simple linear regression is known that $p$ value is $0.656>0.25$, its means that Ho accepted and Hi averse, with the meaning there is no relation between long uses of KB implant with complaint quantity. Researcher implies to health service to be more explain profit and loss in use KB implant.
\end{abstract}

Keywords: long use of KB implant, complain quantity

\section{LATAR BELAKANG}

Di Indonesia pertumbuhan penduduk masih cukup tinggi, sehingga pemerintah mencanangkan program keluarga berencana (KB) (Suratun, 2008). Program keluarga berencana ini mempunyai tujuan program nasional kependudukan dan keluarga berencana diantaranya: tujuan demografis yaitu dapat dikendalikannya tingkat pertumbuhan penduduk berupa penurunan angka fertilitas dari 44 permil pada tahun 1971 menjadi 22 permil pada tahun 1990; tujuan normatif yaitu dapat dihayatinya norma 
keluarga kecil bahagia dan sejahtera (NKKBS) yang pada waktunya akan menjadi falsafah hidup masyarakat Indonesia (Hartanto, 2004).

Akhir-akhir ini animo masyarakat di Indonesia terkait dengan keluarga berencana cenderung menurun, salah satu aspek yang menyebabkannya adalah adanya efek samping atau keluhan terkait penggunaan alat kontrasepsi tersebut. Alat kontrasepsi yang sering mempunyai efek samping dan banyak menimbulkan keluhan adalah kontrasepsi hormonal jenis implant. Efek samping dari KB implant ini antara lain gangguan haid, berat badan bertambah, sakit kepala, gangguan pada sistem kardiovaskuler, dan mengganggu siklus menstruasi (Sarwono, 2000). Dari 30\% peserta KB implant didapatkan $18 \%$ mengalami keluhan-keluhan seperti amenore, nyeri haid, haid tidak teratur, perubahan berat badan.

Banyaknya keluhan KB implant ini diduga salah satu penyebabnya adalah akibat lama penggunaan $\mathrm{KB}$ impalant itu sendiri. $\mathrm{KB}$ implant yang berisi hormon diduga dapat mengganggu sistem secara menyeluruh sehingga menimbulkan keluhan seperti yang tersebut di atas. Untuk memastikan hal tersebut di atas maka perlu dilakukan penelitian tentang " Hubungan Lama Penggunaan KB Implant dengan Jumlah Keluhan pada Akseptor di Puskesmas Junrejo Kota Batu."

\section{METODE}

Penelitian deskriptif korelasional, yang mengkaji hubungan antara lama penggunaan KB implant dengan jumlah keluhan. Penelitian dilakukan pada 3-9 Agustus 2009 di Puskesmas Junrejo Kota Batu dengan menggunakan total sampling yaitu seluruh akseptor KB implant yang mengalami keluhan di Puskesmas Junrejo Kota Batu sebanyak 23 orang.

Instrumen penelitian menggunakan kuesioner yang berisi pertanyaan terkait dengan lama penggunaan dan keluhankeluhan yang dirasakan selama penggunaan KB implant. Setelah data terkumpul, data dianalisis secara univariat dengan distribusi frekuensi dan ditabulasi dalam bentuk tabel, sedangkan untuk analisis hubungan antar variabel lama penggunaan KB implant dan jumlah keluhan dilakukan analisis bivariat dengan menggunakan regresi linier sederhana.

\section{HASIL DAN PEMBAHASAN}

Analisis Univariat

Karateristik Responden Berdasarkan Umur

Tabel 1. Distribusi responden berdasarkan umur di Puskesmas Junrejo Kota Batu

\begin{tabular}{ccc}
\hline Umur & Jumlah & Prosentase $(\%)$ \\
\hline 21-30 tahun & 7 & 30,4 \\
31-40 tahun & 12 & 52,2 \\
41-50 tahun & 4 & 17,4 \\
\hline Total & 23 & 100 \\
\hline
\end{tabular}

Dari tabel 1 diketahui terdapat 7 responden (30,4\%) berumur 21-30 tahun, 12 responden $(52,2 \%)$ umur 31-40 tahun dan sebagian kecil berumur antara 41-50 tahun yaitu 4 responden $(17,4 \%)$.

\section{Karateristik Responden Berdasarkan Jumlah Anak}

Tabel 2. Distribusi data responden berdasarkan jumlah anak di Puskesmas Junrejo Kota Batu

\begin{tabular}{ccc}
\hline Jumlah anak & Jumlah & Prosentase $(\%)$ \\
\hline 1 & 6 & 26,1 \\
2 & 7 & 30,4 \\
3 & 3 & 13,0 \\
4 & 2 & 8,7 \\
5 & 5 & 21,7 \\
\hline Total & 23 & 100 \\
\hline
\end{tabular}

Dari tabel 2 diketahui terdapat 6 responden $(26,1 \%)$ memiliki 1 anak, 7 responden $(30,4 \%)$ memiliki 2 anak, 3 responden $(13,0 \%)$ jumlah anaknya 3,2 
responden $(8,7 \%)$ memiliki 4 anak dan 5 responden $(21,7 \%)$ lainnya mempunyai 5 anak.

\section{Tabulasi Silang Antara Lama KB Implant Dengan Keluhan}

Dari tabel 3 diketahui bahwa responden yang menggunakan $\mathrm{KB}$ implant selama 1 tahun sebanyak 1 responden (4,3\%) masingmasing mengalami 2 dan 4 keluhan, 2 responden $(8,7 \%)$ mengalami 3 keluhan. Responden yang menggunakan KB implant selama 2 tahun sebanyak 2 responden $(8,7 \%)$ masing-masing mengalami 2 dan 3 keluhan. Responden yang menggunakan $\mathrm{KB}$ implant selama 3 tahun sebanyak 1 responden $(4,3 \%)$ masing-masing mengalami 1 sampai 4 keluhan. Responden yang menggunakan KB implant selama 4 tahun sebanyak 1 responden (4,3\%) masing-masing mengalami 1 dan 4 keluhan, 2 responden $(8,7 \%)$ mengalami 2 keluhan, 3 responden (13\%) mengalami 3 keluhan. Responden yang menggunakan KB implant selama 5 tahun sebanyak 1 responden (4,3\%) mengalami 2 keluhan, 3 responden (13\%) mengalami 3 keluhan.

Tabel 3. Tabulasi silang antara lama KB implant dengan keluhan di Puskesmas Junrejo Kota Batu

\begin{tabular}{ccccccc}
\hline Lama KB & \multicolumn{5}{c}{ Jumlah keluhan } & \multirow{2}{*}{ Total } \\
\cline { 2 - 5 } implant & 0 & 1 & 2 & 3 & 4 & \\
\hline \multirow{2}{*}{1} & 0 & 0 & 1 & 2 & 1 & 4 \\
& $(0 \%)$ & $(0 \%)$ & $(4,3 \%)$ & $(8,7 \%)$ & $(4,3 \%)$ & $(17,4 \%)$ \\
2 & 0 & 0 & 2 & 2 & 0 & 4 \\
& $(0 \%)$ & $(0 \%)$ & $(8,7 \%)$ & $(8,7 \%)$ & $(0 \%)$ & $(17,4 \%)$ \\
3 & 0 & 1 & 1 & 1 & 1 & 4 \\
& $(0 \%)$ & $(4,3 \%)$ & $(4,3 \%)$ & $(4,3 \%)$ & $(4,3 \%)$ & $(17,4 \%)$ \\
4 & 1 & 0 & 2 & 3 & 1 & 7 \\
& $(4,3 \%)$ & $(0 \%)$ & $(8,7 \%)$ & $(13 \%)$ & $(4,3 \%)$ & $(30,4 \%)$ \\
& 0 & 0 & 1 & 3 & 0 & 4 \\
& $(0 \%)$ & $(0 \%)$ & $(4,3 \%)$ & $(13 \%)$ & $(0 \%)$ & $(17,4 \%)$ \\
\hline \multirow{2}{*}{ Total } & 1 & 1 & 7 & 11 & 3 & 23 \\
& $(4,3 \%)$ & $(4,3 \%)$ & $(30,4 \%)$ & $(47,8 \%)$ & $(13 \%)$ & $(100 \%)$ \\
\hline
\end{tabular}

Tabel 4. Hasil analisis regresi hubungan lama penggunaan KB

\begin{tabular}{ccccc}
\hline Variabel & $\mathrm{r}$ & $\mathrm{R}^{2}$ & Persamaan garis & $\mathrm{P}$ value \\
\hline $\begin{array}{c}\text { Lama } \\
\text { penggunaan }\end{array}$ & 0,098 & 0,010 & $\mathrm{JK}=2,816+-0,066^{*}$ & 0,656 \\
KB implant & & & Lama KB implant & \\
\hline
\end{tabular}

\section{Analisis Bivariat}

Untuk mengetahui hubungan lama penggunaan KB implant dengan jumlah keluhan pada akseptor di Puskesmas Junrejo Kota Batu, digunakan analisis regresi dan interprestasi pada tabel 4.

Dari tabel 4 diketahui implant dengan jumlah keluhan pada akseptor menunjukkan hubungan yang sangat lemah $(\mathrm{r}=0,098)$ dan berpola positif artinya semakin lama penggunaan semakin banyak jumlah keluhan. Nilai koefisien determinasi 0,010 artinya persamaan garis regresi yang diperoleh menerangkan $1 \%$ variasi prosentasi jumlah keluhan. Hasil uji statistik didapatkan tidak ada hubungan lama penggunaan KB implant dengan jumlah keluhan pada akseptor $(\mathrm{p}=$ 0,656 ).

Dari hasil penelitian dapat kita cermati bahwa keluhan paling banyak adalah 3 keluhan dan terjadi pada penggunaan KB selama 4 tahun, sedangkan keluhan paling sedikit ditemukan pada 3 tahun pertama. Jadi walaupun secara uji statistik tidak ada hubungan antara lama penggunaan KB dengan jumlah keluhan tetapi petugas kesehatan harus waspada terhadap 
munculnya berbagai keluhan akibat penggunaan KB implant di tahun ke 4.

Berbagai keluhan ini dapat terjadi akibat adanya adaptasi tubuh secara fisiologis terhadap KB implant itu sendiri, sehingga penyesuaian tubuh dengan tambahan progestin dari implant dalam waktu lama dapat menyebabkan bertambahnya keluhan, tetapi setelah tahun ke 4 keluhan tersebut berkurang dengan sendirinya akibat kemampuan adaptasi tubuh yang meningkat.

\section{KESIMPULAN DAN SARAN}

Berdasarakan pembahasan dapat disimpulkan bahwa mayoritas sebanyak 7 responden $(30,4 \%)$ menggunakan $\mathrm{KB}$ implant selama 4 tahun dan mayoritas 11 responden $(47,8 \%)$ mengalami 3 keluhan. Berdasarkan uji statistik analisis regresi didapatkan tidak ada hubungan lama penggunaan KB implant dengan jumlah keluhan pada akseptor di Puskesmas Junrejo Batu $(\mathrm{p}=0,656)$.

Saran yang dapat diberikan kepada peneliti selanjutnya adalah diharapkan dapat menggunakan hasil penelitian ini sebagai referensi atau data tambahan dalam melakukan penelitian lain yang berhubungan dengan KB implant seperti faktor-faktor yang mempengaruhi akseptor KB memakai KB implant. Bagi petugas kesehatan diharapkan dapat mewaspadai aseptor KB implant di tahun ke 4 terkait dengan meningkatnya keluhan yang terjadi di tahun ke 4 pada aseptor KB implant. Bagi institusi pendidikan, dari hasil penelitian institusi pendidikan diharapkan meningkatkan kualitas materi dan program pengajaran tentang metode kontrasepsi khususnya tentang kontrasepsi implant. Bagi profesi (tenaga kesehatan) diharapkan dapat lebih memberikan informasi keuntungan dan kekurangan dalam menggunakan $\mathrm{KB}$ implant kepada akseptor KB.

\section{DAFTAR PUSTAKA}

Fajar, I. 2009. Statistika untuk Praktisi Kesehatan. Yogyakarta: Graha Ilmu.

Hartanto, H. 2004. Keluarga Berencana dan Kontrasepsi. Jakarta: Pustaka Sinar Harapan.

Mocthar, R. 1998. Sipnosis Obstetri. Edisi 2. Jakarta: EGC.

Prawirohardjo, S. 1999. Ilmu Kandungan. Jakarta: Yayasan Bina Pustaka.

Riski. 2008. Haid Tidak Teratur. (online) http: www.geocities.com. Diakses pada 16 Desember 2008.

Romadani. 2008. Susuk KB. (online) http: www.perawatonline.com. Diakses pada 21 Desember 2008.

Setiadi. 2007. Konsep dan Penulisan Riset Keperawatan. Yogyakarta: Graha Ilmu.

Suratun. 2008. Pelayanan Keluarga Berencana dan Pelayanan Kontrasepsi. Jakarta: Trans Info Media.

Suyanto. 2008. Alat Kontrasepsi Bawah Kulit. (online) http: www.bkkbn.go.id. Diakses pada 23 Desember 2008.

Speroff, L. 2003. Pedoman Klinis Kontrasepsi. Jakarta: EGC.

Yudha. 2008. Anda Perlu Tahu Tentang Berat Badan. (online) http: www.afic.org. Diakses pada 23 Desember 2008.

Yulia. 2009. Gangguan Menstruasi. (online) http: www.rileks.com. Diakses pada 11 Juni 2009.

Yosemite. 2008. Kontrasepsi. (online) http: www.wordpress.com. Diakses pada 16 Desember 2008. 